\title{
Economic Security of Ukraine's Railway Transport in the Context of National Security
}

\author{
Mariia Chekhovska * [0000-0001-8135-7770], Iryna Manzhul [0000-0002-6507-871X], \\ Olena Lisovska ${ }^{[0000-0002-2272-3053]}$
}

National Academy of Security Service of Ukraine, Kyiv, Ukraine

*chemary@ukr.net

\begin{abstract}
The authors consider the legislative and economic prerequisites for the need to ensure the economic security of Ukraine's railway transport in the context of national security. The research methodology is composed of such methods as a theoretical generalization for further clarification of the conceptual apparatus of railway transport economic security, a legalistic method for analysis and systematization of legal bases in the field of Ukraine's national security, an abstract-logical method for theoretical generalization and formulation of research conclusions, etc. Taking into account the dynamics and nature of railway freight transportation, conclusions about the strategic place of the industry in ensuring sustainable development of the state and, accordingly, the need to protect its economic security were drawn. The authors outline the legal principles of economic security of railway transport in the system of legal regulation of Ukraine's security policy. The article provides the author's definition of “economic security of railway transport" concept, based on current tendencies in national security.
\end{abstract}

Keywords: economic security, national security, railway transport, sustainability, capacity.

\section{INTRODUCTION}

Thirty years of Ukrainian independence is a vivid example of the emergence and change (following internal and external factors) of challenges and threats to the state economic security, among which both purely national and international ones stand out. An important prerequisite for counteracting threats to the economic security is their prevention or minimization of negative consequences, where world experience or the development of an adequate national path is appropriate. And, at the same time, failure to solve problems at the nascent stage causes the subsequent emergence of complex threats, overcoming which will require a significant amount of legal, organizational, financial and economic resources.

Historically, Ukraine's railway transport plays an important role in the development of the state's economy. First of all, railway transport makes a significant share of freight turnover among other modes of transport, in particular, the automobile one. Secondly, railway transport performs a necessary social function of passengers' transportation. Thirdly, railways carry out the cargo transportation of the strategic industries, including the agro-industrial complex, the fuel and energy industry, the metallurgical and mining industries, and the chemical industry. Freight transportation of the defense industry and the military-industrial complex, as well as military transportation, is carried out by enterprises of the industry to meet the needs of Ukraine's security and defense sector.

Taking into account the long process of the railway transport reformation, economic crises and military aggression of the Russian Federation against our state, an important prerequisite for Ukraine's national security is, in our opinion, sustainable development of the railway industry and systemic economic security support. These circumstances have determined the relevance of this study, which aims to identify threats to the economic security of railway transport in present conditions, ways to minimize or prevent them, as well as to formulate capabilities to ensure the economic security of Ukraine's railway transport.

\section{RESEARCH METHODOLOGY}

The theoretical and methodological basis of the study is composed of the scientific works of modern foreign and domestic scientists and specialists on the problems of economic security of railway transport, national security, etc. The information base of the study 
consists of Ukraine's current legislation, materials of the State Statistics Service of Ukraine, the Ministry of Infrastructure of Ukraine and the joint-stock company "Ukrzaliznytsia".

To solve this goal, the following forms, ways and research methods were used: systematic approach - to determine the components of the economic security of railway transport; theoretical generalization - to clarify the conceptual apparatus of the economic security of railway transport; historical - to study the processes of emergence, formation and development of new approaches to the formation of the national security system and its components; legalistic - to analyze legal sources in the field of Ukraine's national security and their systematization; economic-statistical and economic-mathematical - to analyze the dynamics of performance indicators of the railway industry for the reporting period; abstract-logical - to generalize and formulate the conclusions.

The study of the economic security of Ukraine's railway transport in general and its structural enterprises is given attention in the works of $\mathrm{Zh}$. S. Kostyiuk, B. B. Ostapiuk, I. I. Rekun, etc. The research in the field of national security is much widely presented in the works O. S. Vlasiuk, B. P. Horbulin, O. P. Dzoban, V. H. Pylypchuk. At the same time, the researchers have not considered the question of the economic security content of railway transport in the components of national security.

\section{RESULTS}

Current trends in national security policy and analysis of railway transport activity have allowed us to define the essence of the economic security of railway transport as the resistance of enterprises, institutions and organizations of a single production and technological complex of railway transport enterprises to real and potential threats under conditions of ensuring stability and strengthening capacities in its activities. The analysis of the safety environment allowed formulating the basic components of railway transport capacities, in particular, the legislative framework, organizational structure and management, professional level and education, resource provision.

\section{DISCUSSION}

Active study of the basic principles of the economic security of Ukraine's railway transport is certainly connected with the study of the state's economic security.

The systematization of threats to the economic security of railway transport enterprises was presented in the works of P. V. Lapin and S. P. Mishchenko [1, 2]. A. V. Rachynska classified the risks in railway transport as conditions for increasing economic security [3]. Risks and threats to the economic security of railway transport were identified in the works of V. L. Dykan [4]. Scientists S. M. Synytsia and O. V. Vakun studied the peculiarities of the economic security management of railway transport enterprises [5]. Estimated figures of the economic security of railway transport enterprises were studied by T. O. Murenko [6]. Systematization of factors influencing the economic security of railway transport was carried out by O. Yu. Cherednychenko [7] etc. [8-10]

Elaboration of scientific sources to define the essence of "economic security of railway transport" concept allowed us to conclude that there is no single approach in its formulation (Table 1).

Nowadays, following Ukraine's national security policy and the chosen course for European and EuroAtlantic integration, the construction of a national system of resilience and capacity planning has become relevant [11-14]. In the context of ensuring the economic security of railway transport, sustainability is understood by the authors of this article as the ability of enterprises, institutions and organizations of railway transport, as well as the capacity of their employees, to quickly adapt to changes in the safety sector and operate with the aim to minimize vulnerabilities $[15,16]$ caused by the external and internal environment. Similarly, capacity planning is understood as the definition of the main directions of Ukraine's transport policy implementation, strategic goals of railway transport development and the expected results of their achievement, taking into account the real and potential threats to the economic security of railway transport.

Accordingly, taking into account current tendencies in support of the national security components, the economic security of railway transport, in our opinion, should be understood as the resilience of enterprises, institutions and organizations of a single production and technological complex of railway transport enterprises to real and potential threats under conditions of ensuring stability and strengthening capacities in its activities.

Legal basis for ensuring the economic security of railway transport is the Law of Ukraine "On the National Security of Ukraine" in the context of protection of such Ukraine's fundamental national interests as sustainable development of the national economy to ensure growth and quality of the nation's life [17]. In addition, the Law states that Ukraine's policy in the spheres of national security and defense is aimed at ensuring the economic security of Ukraine, and thus at ensuring its component - the economic security of railway transport.

The National Security Strategy of Ukraine also emphasizes the need to create an effective system of security and resilience of critical infrastructure, the objects of which include railway transport [11]. 
Table 1. Scientific views on the essence of the "economic security of railway transport" concept

\begin{tabular}{|l|l|}
\hline \multicolumn{1}{|c|}{ Author } & \multicolumn{1}{|c|}{ Definition of the concept } \\
\hline $\begin{array}{l}\text { Synytsia, S. M., } \\
\text { Vakun, O. V., 2020 }\end{array}$ & $\begin{array}{l}\text { "such a state of the railway transport enterprise, which ensures the stability of its } \\
\text { functioning and sustainable development in future periods" [5, p. 114] }\end{array}$ \\
\hline Kostiuk, Zh. S., 2013 & $\begin{array}{l}\text { "the state of railway transport enterprises, which helps to achieve organizational and } \\
\text { technical unity, high quality and efficiency of transport services, which ensures the efficient } \\
\text { functioning and sustainable development of railway transport based on a targeted set of } \\
\text { measures that aim to prevent or mitigate the negative impact of external and internal } \\
\text { threats" [18, p. 177] }\end{array}$ \\
\hline Rekun, I. I., 2015 & $\begin{array}{l}\text { "a system of long-term management of financial and economic security taking into account } \\
\text { existing and potential threats and risks, the definition of operational and future goals of the } \\
\text { economic security system, formation of plans' strategy and flexibility following changes in } \\
\text { the internal and external institutional environment of the enterprise" [19, p. 320] }\end{array}$ \\
\hline Mezhokh, Z. P., 2007 & $\begin{array}{l}\text { "is determined by the strategic priorities and parameters of its functioning, which meet the } \\
\text { transportation needs of cargo owners and passengers, the quality and competitiveness of } \\
\text { transport products while maintaining sustainable work, social security of employees and } \\
\text { financial stability of the industry" [20, p. 41] }\end{array}$ \\
\hline
\end{tabular}

It should be noted that the National Economic Strategy for the period up to 2030 pays special attention to railway transport in terms of challenges and barriers to further development and identifies ways to overcome them.

It is also important to mention that the Law of Ukraine "On Railway Transport" emphasizes that "the activity of railway transport as part of a unitary transport system contributes to the proper functioning of all sectors of public production, social and economic development and strengthening the state's defense capacities", which also indicates the need to ensure, in particular, the economic security of railway transport [21].

As noted earlier, Ukraine's railway transport is an important component of strengthening the welfare of our country, taking into account that the state of ensuring its economic security has an impact on the overall situation with Ukraine's national security.

Thus, in recent decades the share of railway transport in goods transportation by other modes of transport has fluctuated from $23 \%$ in 2000 , to $24 \%$ in 2010 and $20 \%$ in 2019 [22]. At the same time, the distribution of freight turnover by modes of transport shows favorable statistics for railway transport - from $44 \%$ in 2000 to $52 \%$ in 2010 and $51 \%$ in 2019 . It is also impossible to avoid such an indicator as the transportation of 1 ton of cargo by different modes of transport: in 2019 this indicator reached $581 \mathrm{~km}$ for railway transport against $57 \mathrm{~km}$ for the automobile one.
It should be noted that the reduction of the abovementioned indicators began in 2014, due to the military aggression of the Russian Federation against Ukraine, namely the reduction of transit cargo and the termination of railway connection with the aggressor state, as well as the temporary occupation of the Autonomous Republic of Crimea and the City of Sevastopol and some districts of Donetsk and Luhansk regions.

Freight transportation of strategic industries is also evidence of railway transport's contribution to national security. Thus, it is Ukraine's railways that transport significant volumes of coal, oil and oil products, ferrous metals, ore, and grain cargo. In particular, in 2019 they transported coal $-19 \%$, ore $-24 \%$, grain $-13 \%$ of the total railway traffic [22].

As noted above, the reduction in railway transport performance began in 2014 , for which there is no data at all. For clarity, the indicators of 2013 were included (Table 2). It can be seen that in 2019, compared to 2013, the transportation volume of coal, oil and oil products, ferrous metals, etc. decreased almost twice. Also in the same period, the transportation of grain cargo increased from 23 million tons to 40 million tons. In general, if to compare the volumes of cargo transportation of strategic industries by railways in 2019 and 2000, there is a decrease in the main nomenclature and an increase in more than 6 times of grain transportation volume.

An important element in ensuring national security is the implementation of military transportation by 
railway enterprises. Thus, the normative documents of the Ministry of Defense of Ukraine stipulate that railways conduct transportation of military units under conditions of "sufficient time and the need to move military units to a distance greater than the day' $\mathrm{s}$ march" and with the aim to preserve motor resources and fuel [23]. If necessary, such rolling stock as railway passenger (including human) and freight (covered, platforms, gondola) cars, is used.

A separate Resolution of the Cabinet of Ministers of Ukraine regulates "the mechanism of military railway transportation, their planning, organization and provision, calculations for such transportation, maintenance and service of railway access tracks to military units, institutions and organizations of the Armed Forces in peacetime and special period" [24]. The document governs the creation of separate structural subdivisions - departments of military communications on the railways, which should ensure the interaction of the Ministry of Defense of Ukraine with enterprises, institutions and organizations of railway transport - in the locations of railway departments.

Table 2. Transportation of goods by public railway transport, million tons

\begin{tabular}{|l|c|c|c|c|c|c|c|c|c|c|}
\hline Cargo / Year & 2000 & 2010 & $\begin{array}{c}\text { in \% up } \\
\text { to } 2000\end{array}$ & 2013 & $\begin{array}{l}\text { in \% up } \\
\text { to } 2010\end{array}$ & 2015 & $\begin{array}{l}\text { in \% up } \\
\text { to 2013 }\end{array}$ & 2019 & $\begin{array}{l}\text { in \% up } \\
\text { to } 2015\end{array}$ & $\begin{array}{l}\text { in \% up } \\
\text { to } 2000\end{array}$ \\
\hline coal & 98 & 118 & 120.4 & 119 & 100.8 & 73 & 61,3 & 59 & 80.8 & 60.2 \\
\hline oil/oil products & 27 & 31 & 114.8 & 23 & 74.1 & 17 & 73.9 & 12 & 70.5 & 44.4 \\
\hline ferrous metals & 45 & 40 & 88.8 & 39 & 97,5 & 29 & 74.3 & 24 & 82.7 & 53.3 \\
\hline ore & 65 & 82 & 126.1 & 88 & 107.3 & 85 & 96.5 & 75 & 88.2 & 115.3 \\
\hline grain & 6 & 13 & 216.6 & 23 & 176.9 & 29 & 126.1 & 40 & 137.9 & 666.7 \\
\hline
\end{tabular}

Source: data from the State Statistics Service of Ukraine [22].

According to official data, the Department of Military Communications on Railway Transport of Ukraine performs railway transportation to ensure activities in the interests of the Armed Forces of Ukraine, including during command post exercises, transportation of personnel and equipment of the Armed Forces of Ukraine during international military exercises, in particular in the framework of the international cooperation program "Partnership for Peace", as well as the rotation of peacekeeping forces [25].

It should be noted that railway transport enterprises are entrusted with ensuring "implementation of military railway transportation plans; provision of rolling stock for military railway transportation; movement of military trains by railway according to the relevant schedule; military echelons, military vehicles moving under the protection of military guards, water, heating, lighting; provision of loading and unloading devices and removable military equipment following legislative regulations; control over the movement of military echelons, as well as in some cases of military transport, their priority loading and delivery to the destination" [24].

It should also be mentioned that an important prerequisite for ensuring security at critical infrastructure facilities, which are enterprises and railway transport facilities, is the activity of a special department within the structure of the joint-stock company "Ukrzaliznytsia", which is responsible for organization and control over the implementation of legislative regulations on mobilization training, mobilization and civil defense in the special period of railway transport transfer from peaceful to martial law by the staff, structural subdivisions and branches of the enterprise [26].

Military activities on the territory of our state gave impetus to the use of military means for completely peaceful purposes. Thus, the use of unmanned aerial vehicles (UAVs) can be considered as one of the modern means of ensuring the economic security of railway transport. Both foreign (Maghazei O. \& Steinmann M., 2020) and domestic (Lapin P. V. \& Katsman N. D., 2021) scientists emphasized the technological capabilities of UAVs in the activity of railway transport. In particular, it is assumed that the prospects for the use of UAVs are not only in the implementation of visual control or monitoring, namely in the process of goods protection [27], but also with the technology improvement - in project management in railway transport [28]. Undoubtedly, the use of UAVs is not only to ensure the safety of goods, but also the preservation and diagnosis of rolling stock, infrastructure objects, counteraction to terrorist threats and prevention of critical situations, railway accidents and more.

As noted above, an important prerequisite for 
ensuring the economic security of railway transport, based on the threats and challenges to its activities, or analysis of the security environment, is to determine its capacity. Thus, in our opinion, among the basic components of railway transport capacity can be identified the following: legislative framework, organizational structure and management, professional level and education, resource provision. This choice of components is due, in particular, to the lack of the updated Law of Ukraine "On Railway Transport of Ukraine" and the subordinate legislation; periodic replacement of management and the lack of clear transparent criteria for effective work; reduction of the requirements for the professional staff level; the unresolved problem of the critical level of rolling stock wear, etc. Thus, a comprehensive approach to solving the problems of the economic security of railway transport and their prospective analysis will prevent and minimize the consequences of negative tendencies.

\section{CONCLUSIONS}

The economic security of railway transport is associated with many components of national security, in particular, technogenic security (train performance security), environmental security (protection of the environment from pollution by railway transport), military security (security of military transportation and cargo), information security (automation and signalization in railway transport), personnel security (professional education of employees, the activities of the supervisory board), because the gaps in these areas directly influence the financial performance of the industry.

Taking into account new approaches to national security, the economic security of railway transport also needs to be renewed. Thus, we stressed the need to ensure the sustainability and capacity strengthening of enterprises in the industry, which are achieved by reducing the level of taxation (property tax, land tax, value-added tax, etc.), the introduction of "zero" tax rates (in particular, value-added tax on all types of passenger traffic), as well as intensification of digital technologies and services introduction.

\section{REFERENCES}

[1] Lapin, P.V. (2016), "The essence of "threat to the economic security of railway transport enterprises" concept", Ekonomika ta derzhava, no. 10, pp. 63-68, available at: http://nbuv.gov.ua/UJRN/ecde_2016_10_16

[2] Mishchenko, S.P. (2014), "Threats to the economic security of railway transport enterprises in terms of industry reformation, Naukovyi visnyk Khersonskoho derzhavnoho universytetu. Seriia: Ekonomichni nauky, no. 9 (3), pp. 121-125, available
http://nbuv.gov.ua/UJRN/Nvkhdu_en_2014_9\%28 $3 \% 29 \_30$

[3] Rachynska, A.V. (2016), "Classification of the risks on railway transport as a basis for formation of the economic security of its functioning", available at: https://economyandsociety.in.ua/journals/6_ukr/14 .pdf

[4] Dykan, V. Tokmakova, I. Pavlichenko, V. Cherednychenko, O. and Korin, M. (2019), "The concept of management of economic security of the railway transport in the context of overcoming the manifestations of a systemic crisis", SHS Web of Conferences, no. 67, pp. 6, DOI: $10.1051 /$ shsconf/20196706014

[5] Synytsa, S.M. and Vakun, O.V. (2020), "Peculiarities of the economic security management of railway transport enterprises", Prychornomorski ekonomichni studii, no. 51, pp. 112-117, DOI: 10.32843/bses.51-

[6] Murenko, T.O. (2015), "Interconnection of the estimated indicators of the economic security of railway transport enterprises", Ekonomichnyi analiz, vol. 19, no. 2, pp. 103-108, available at: http://nbuv.gov.ua/UJRN/ecan_2015_19(2)_17.

[7] Cherednychenko, O.Yu. (2014), "Systematization of factors influencing the economic security of railway transport", Visnyk ekonomiky transportu $i$ promyslovosti, no. 48, pp. 73-78, available at: http://nbuv.gov.ua/UJRN/Vetp_2014_48_16

[8] Korystin, Oleksandr and Svyrydiuk, Nataliia (2021), "Activities of Illegal Weapons Criminal Component of Hybrid Threats", Proceedings of the International Conference on Economics, Law and Education Research (ELER 2021), vol. 170, 22 March, pp. 86-91, DOI 10.2991/aebmr.k.210320.016

[9] Tkachenko, Volodymyr Kwilinski, Aleksy Korystin, Oleksandr Svyrydiuk, Natalia and Tkachenko, Iryna (2019), “Assessment of information technologies influence on financial security of economy", Journal of security and sustainability issues, march, vol. 8, no. 3, pp. 375385, DOI: 10.9770/jssi.2019.8.3(7)

[10] Korystin, Oleksandr and Svyrydiuk, Nataliia (2021), "Formation of security competences in law enforcement activities", Nauka $i$ Pravookhorona, vol. 1 (51), pp. 191-198, DOI: $10.36486 / \mathrm{np} .2021 .1(51) .20$

[11] Decree of the President of Ukraine "On the decision of the National Security and Defense 
Council of Ukraine of September 14, 2020" "On the National Security Strategy of Ukraine" of September 14, 2020 № 392/2020, available at: https://zakon.rada.gov.ua/laws/show/392/2020\#Te $\mathrm{xt}$

[12] Resolution of the Cabinet of Ministers of Ukraine of March 3, 2021 № 179 "On approval of the National Economic Strategy for the period up to 2030", available at: https://www.kmu.gov.ua/npas/prozatverdzhennya-nacionalnoyi-eko-a179

[13] Order of the Ministry of Defense of Ukraine of December 22, № 484 "On approval of the Procedure for organization and implementation of defense planning in the Ministry of Defense of Ukraine, the Armed Forces of Ukraine and other components of the Defense Forces", available at: https://zakon.rada.gov.ua/laws/show/z019621\#Text

[14] Aaron Zimba, Zhaoshun Wang and Luckson Simukonda (2018), "Towards Data Resilience: The Analytical Case of Crypto Ransomware Data Recovery Techniques", International Journal of Information Technology and Computer Science, vol. 10, no. 1, pp. 40-51, DOI: $10.5815 /$ ijitcs.2018.01.05

[15] Issah Baako and Sayibu Umar (2020), "An Integrated Vulnerability Assessment of Electronic Commerce Websites", International Journal of Information Engineering and Electronic Business, vol. 12, no. 5, pp. 24-32, DOI: 10.5815/ijieeb.2020.05.03

[16] Samuel Ndichu, Sylvester McOyowo, Henry Okoyo and Cyrus Wekesa (2019), "A Domains Approach to Remote Access Logical Vulnerabilities Classification", International Journal of Computer Network and Information Security, vol. 11, no. 11, pp. 36-45, DOI: $10.5815 /$ ijcnis.2019.11.05

[17] Law of Ukraine " On National Security of Ukraine” from June 21, 2018 № 2469-VIII, available at: https://zakon.rada.gov.ua/laws/show/2469-19\#Text

[18] Kostiuk, Zh.S. (2013), "The essence of the concept of "economic security of railway transport enterprises"”, Visnyk ekonomiky transportu $i$ promyslovosti, no. 41, pp. 173-179, available at: http://nbuv.gov.ua/UJRN/Vetp_2013_41_45

[19] Rekun, I.I. (2015), Transformatsiia systemy ekonomichnoi bezpeky pidpryiemstv zaliznychnoho transportu [Transformation of the system of the economic security of railway transport enterprises: monograph], monohrafiia, DNUZT, Vydavnyk: Kolor-prynt, Dnipropetrovsk, Ukraine, available at: http://eadnurt.diit.edu.ua/jspui/bitstream/12345678 9/4848/1/Rekun_monograph.pdf

[20] Mezhokh, Z.P. (2007), "Problems of the economic security management of railway transport (theory, methodology, solutions)", Abstract of $\mathrm{Ph} / \mathrm{D}$. dissertation, available at: https://static.freereferats.ru/_avtoreferats/0100339 4996.pdf

[21] Law of Ukraine № 273/96-BP of July 4, 1996 "On Railway Transport", available at https://zakon.rada.gov.ua/laws/show/273/96$\% \mathrm{D} 0 \% \mathrm{~B} 2 \% \mathrm{D} 1 \% 80 \#$ Text

[22] Transport: statistics, available at: http://www. ukrstat.gov.ua/operativ/menu/menu_u/tr.htm

[23] Order of the Ministry of Defense of Ukraine of September 5, 2013 № 595 “On approval of the Regulations on military transportation by rail, sea, river and air", available at: https://zakon.rada.gov.ua/laws/show/z166213\#Text

[24] Resolution of the Cabinet of Ministers of Ukraine of November 4, 2015 № 891 “On approval of the Procedure for organizing the activities of railway transport during military railway transportation", available

https://zakon.rada.gov.ua/laws/show/891-2015$\%$ D0\%BF\#Text

[25] Department of Military Communications, available at: https://www.uz.gov.ua/about/general_ informat ion/main_departments/management_of_ military_communications/

[26] Special Department is a structural subdivision of the management apparatus of PJSC "Ukrzaliznytsia", available at: https://www.uz.gov.ua/about/general_information/ main_departments/first_management/

[27] Lapin, P. (2021), Use of unmanned aerial vehicles for protection of goods and objects on railway transport, Systemy upravlinnia, navihatsii ta zviazku. Zbirnyk naukovykh prats, no. 1 (63), pp. 134-137, DOI: 10.26906/SUNZ.2021.1.134

[28] Maghazei, O. and Steinmann, M. (2020), "Drones in Railways: Exploring Current Applications and Future Scenarios Based on Action Research", European Journal of Transport and Infrastructure Research, no. 20 (3), pp. 87-102, DOI: 10.18757/ejtir.2020.20.3.4612 